This is the peer reviewed version of the following article: Sánchez-Hernández J., and Nunn A. D. (2016) Environmental changes in a Mediterranean river: implications for the fish assemblage, Ecohydrol., 9: 1439-1451, which has been published in final form at doi: 10.1002/eco.1737. This article may be used for non-commercial purposes in accordance With Wiley Terms and Conditions for self-archiving.

\title{
Environmental changes in a Mediterranean river: implications for the fish
}

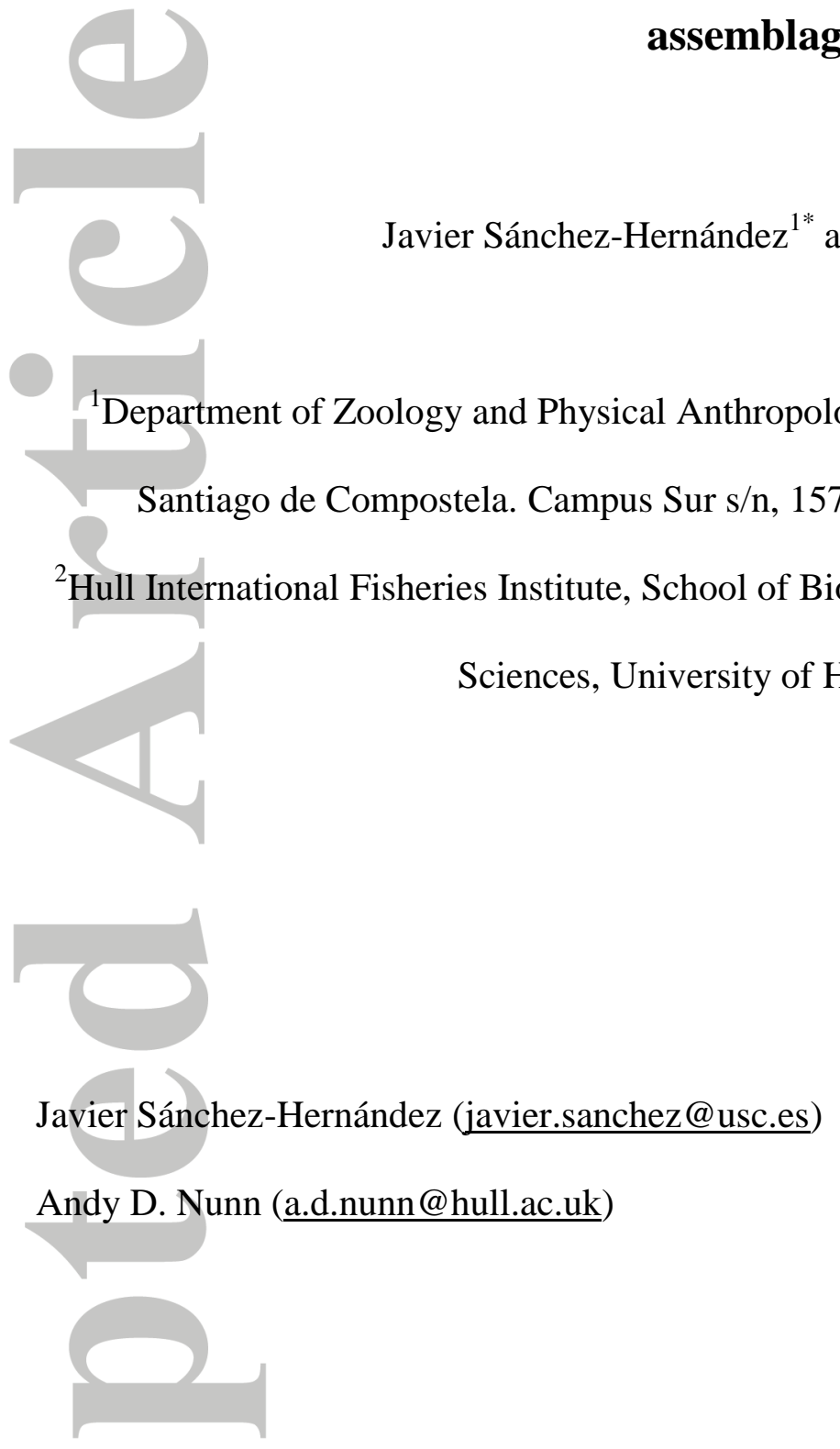

Running head: Impacts of environmental change on Mediterranean fish

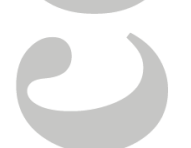

*Author to whom correspondence should be addressed. Tel.: +34 630156 186; e-mail: javier.sanchez@usc.es

This article has been accepted for publication and undergone full peer review but has not been through the copyediting, typesetting, pagination and proofreading process which may lead to differences between this version and the Version of Record. Please cite this article as doi: $10.1002 /$ eco.1737 


\section{Abstract}

This study examined the impacts of climate change on hydrology and fish population dynamics in a river in central Spain. The objectives were to: (i) contextualise long-term trends in the hydrology (1943-2012) and climate (1985-2011) of the study area, and (ii) identify the environmental factors driving fish population dynamics (1998-2012). Air and water temperatures progressively increased over the study period, whereas there were substantial reductions in mean spring river discharges but increases in peak-flow discharges during the spawning and early larval period of endemic cyprinids in recent decades. In particular, the changes in spring river discharges could have fundamental implications for the future status of the endemic cyprinids because this study revealed a positive influence of stable and low flow conditions during the spawning and early larval period (in late spring) on recruitment success (young-of-the-year densities). The density of young-of-the-year Salmo trutta appeared most influenced by flow conditions during fry emergence and the early larval period (in early spring), with the highest densities associated with low peak-flow hydrological pulses. Overall, fish abundances were significantly influenced by the frequency and duration of high and low hydrological pulses, but there were interspecific and ontogenetic differences in their influence. We conclude that although it is widely accepted that global warming should favour cyprinid over salmonid species, future shifts in hydrology due to climate change could negatively affect some cyprinids, including endemic species.

Keywords: abundance, endemic species, flow, threatened species, water temperature, climate

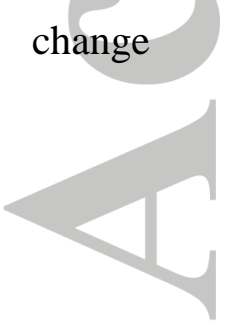




\section{Introduction}

The study of changes in the fish assemblages of freshwater systems has received considerable attention over the last two decades. Fish communities are structured by a wide range of abiotic factors, including water quality, physical habitat and hydrological regime (e.g. Jackson et al. 2001; Bernardo et al. 2003; Kiernan and Moyle 2012), as well as biotic factors, such as density-dependent mechanisms, intra- and interspecific competition and predatorprey interactions (e.g. Abrams 2000; Forrester et al. 2006; Vincenzi et al. 2012). Thus, fish population dynamics in the wild are established as a consequence of the interactions among biotic and abiotic factors.

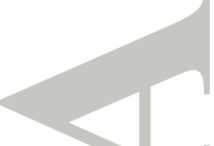

Of all these factors, water temperature and hydrology have been considered as key variables affecting the dynamics of fish populations (e.g. Elliott 1994; Taniguchi et al. 1998). Water temperature may affect fish directly, through its effects on survival, feeding and growth, or indirectly, through its effects on both prey and predator populations (e.g. Elliott 1994). Overall, the negative effects of temperature increases on fishes are well documented and much attention has been paid by many researchers (Elliott and Elliott 2010 and references therein). High water temperatures and low dissolved oxygen during summer droughts are pivotal factors in fish summer survival (e.g. Closs and Lake 1996; Matthews and MarshMatthews 2003). In addition, interannual differences in river discharge during fish hatching may cause variations in recruitment success, and thereby in fish population dynamics (e.g. Cattanéo et al. 2002; Nunn et al. 2007; Cowx et al. 2012). The effects of flow conditions may vary among sympatric species, for example some cyprinids are vulnerable to droughts, whereas others are more sensitive to floods (Magalhães et al. 2007). Similarly, Cattanéo et al. (2001) found that high flow conditions during the spawning period could lead to an increase in the abundance of some cyprinid species, but a decrease in other sympatric cyprinids. Most 
studies in running waters have examined the influence of flow and temperature on fish growth and recruitment success, but few have assessed their influence on the density and size structure of fish assemblages. However, shifts in both flow conditions and water temperatures through climate change will produce a scenario in which it is reasonable to expect that some fish species will be negatively affected, whereas others, such as warm-water species at high latitudes or altitudes, could be enhanced.

Substantial changes in both flow conditions and water temperatures are predicted to occur in the next few decades as a consequence of climate change (e.g. Gómez-Navarro et al. 2011; Vautard et al. 2014), and it is expected that freshwater fish assemblages will undergo considerable changes in structure and diversity as a result (e.g. Tisseuil et al. 2012; Buisson et al. 2013; Tedesco et al. 2013). Fish have species-specific optimal and tolerance ranges (Matthews and Maness 1979; Beitinger et al. 2000), and climate change scenarios predicting higher water temperatures in the future are likely to give an advantage to thermophilic species, such as some cyprinids, in comparison with salmonid species (e.g. Daufresne et al. 2003; Matulla et al. 2007; Almodóvar et al. 2012). It should be noted, however, that the majority of studies on the impacts of climate change on fishes have focused on salmonids as model species (e.g. Jonsson and Jonsson 2009; Elliott and Elliott 2010; Santiago et al. 2016), and that little is known about the possible effects on cyprinids -the largest vertebrate family in the world- because how most species will respond to new environmental conditions is unknown (Jackson and Mandrak 2002; Daufresne et al. 2003; Graham and Harrod 2009; Nunn et al. 2010).

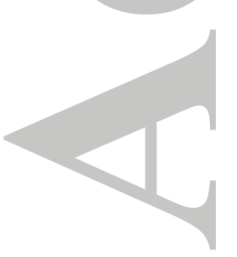


A particular concern for the Mediterranean region is the lack of information on the possible consequences of climate change for endemic cyprinid populations (see Magalhães et al. 2007; Tedesco et al. 2013), even though warming predictions under climate change in this region are well documented (Giorgi and Lionello 2008 and references therein). As a consequence of climate change, Mediterranean rivers are suffering important reductions in winter and spring river discharges, but also increases in peak-flow discharges in recent decades because of extreme weather events (e.g. Zanchettin et al. 2008; Morán-Tejeda et al. 2010). This is important because some endemic fish species are already under immediate threat of extinction (Freyhof and Brooks 2011), which could be exacerbated by changes in hydrology. Indeed, a recent study predicted a significant increase in fish extinctions in Mediterranean rivers due to climate change, and that such regional extinctions will involve a global net biodiversity loss because riverine fish assemblages in those territories are characterized by a high level of endemism (Tedesco et al. 2013 and references therein).

This study examined the impacts of climate change on hydrology and fish population dynamics in a Mediterranean river. The objectives were to: (i) contextualise long-term trends in the hydrology and climate of the study area, and (ii) identify the environmental factors driving fish population dynamics. The rationale was that the effects of climate change on water temperature and hydrology (e.g. Zanchettin et al. 2008; Vautard et al. 2014) could have adverse implications for fish population dynamics, especially of endemic species. The hypotheses were thus that: (i) environmental conditions have changed in recent decades due to climate change, and (ii) changes in fish population dynamics can be explained by shifts in environmental variables, particularly during egg incubation and the early larval period. The possible implications of environmental changes for fish assemblages in Mediterranean 
climate regions (i.e. areas surrounding the Mediterranean Sea and parts of America, Australia, Africa and Asia) are discussed.

\section{Materials and methods}

Study area

The study area was located in the headwater of the Tormes basin, central Spain (Figure 1). The area has a typically continental Mediterranean climate, with extreme differences between temperatures in summer and winter. The hydrology is characterised by a snow-rainfall regime, with the highest annual flows occurring during spring (Ceballos-Barbancho and Morán-Tejeda 2006), and there are no significant flow regulation structures (AlonsoGonzález et al. 2008). The fish community is composed by native fish species: brown trout Salmo trutta L. (hereafter trout), northern straight-mouth nase Pseudochondrostoma duriense (Coelho, 1985) (hereafter nase), northern Iberian chub Squalius carolitertii (Doadrio, 1988) (hereafter chub), and Iberian barbel Luciobarbus bocagei (Steindachner, 1864) (hereafter barbel), the latter three of which are endemic. A recent decline in the chub population has been documented, but the populations of trout and nase appear stable (Sánchez-Hernández et al. 2015). The situation for the barbel is critical and local extirpations in the study area could now be occurring (Sánchez-Hernández et al. 2015).

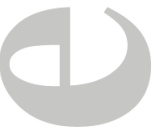

\section{Abiotic parameters}

Daily flow records for the River Tormes were compiled from gauging station number 02006 (UTM 30T 314785E 4468115N, altitude: $1377 \mathrm{~m}$; catchment area: $88 \mathrm{~km}^{2}$ ). Four hydrological parameters $\left(\mathrm{m}^{3} / \mathrm{s}\right)$ were compiled from October 1943 to September 2012: mean daily flow for each month $\left(Q_{\text {med }}\right)$, mean minimum daily flow for each month $\left(Q_{\text {min }}\right)$, mean maximum daily flow for each month $\left(\mathrm{Q}_{\max }\right)$ and maximum peak-flow for each month $\left(\mathrm{Q}_{\text {peak }}\right)$. 
Hydrological studies generally standardise streamflow characteristics for use as indicators of hydrologic alteration (IHA), with the 75th percentile (high pulse) and 25th percentile (low pulse) considered of particular ecological relevance (e.g. Richter et al. 1996; Nicola et al. 2009; Knight et al. 2014). The frequency (no.) and duration (days) of high (daily discharge $>2.150 \mathrm{~m}^{3} / \mathrm{s}$ ) and low (daily discharge $<0.300 \mathrm{~m}^{3} / \mathrm{s}$ ) hydrological pulses during specific periods (see below) were therefore calculated. In addition, the rate of change in discharge was calculated as the mean of both positive (increasing) and negative (decreasing) changes in discharge between consecutive days, and the number of reversals was measured as the number of times river discharge switched between 'positive' and 'negative' periods (Nicola et al. 2009; Bejarano et al. 2010).

Monthly mean water temperature data $\left({ }^{\circ} \mathrm{C}\right.$, January 1996 to December 2012) were obtained from El Barco de Ávila gauging station (UTM 30T 288835E 4466575N), and climatic data (mean air temperature and total precipitation per month, 1985 to 2011) were obtained from meteorological station number 2444 (UTM 30T 357980E 4502279N, altitude: $1130 \mathrm{~m}$ ).

\section{Biotic parameters}

Fish surveys were conducted at six sites from 1998-2002 (Alonso-González 2003; AlonsoGonzález et al. 2008) and 2006-2012 (this study) (Figure 1), except in 2010 when only four of the sites were surveyed (70 surveys in total). The fish populations were surveyed in summer by three-pass removal electrofishing using a 2200-W generator. Fishes were identified to species level, counted, measured for fork length (FL; nearest $1 \mathrm{~mm}$ ) and returned to the river. The low prevalence and abundance of barbel prevented their inclusion in the study. 


\section{0}

The density (fish $/ \mathrm{m}^{2}$ ) of each fish species was calculated using the Zippin multiple-pass depletion method (Zippin 1956); when no depletion in catches was achieved (e.g. chub in some surveys), a minimum density per unit area was calculated. Young-of-the-year (YOY) of each species were identified using Petersen's length frequency analysis (LFA) method (Petersen 1982) to explore differences in the annual recruitment, and chub, nase and trout larger than 100, 150 and 175 mm, respectively, were considered sexually mature (LobónCerviá and Elvira 1981; Lobón-Cerviá et al. 1986; Nicola and Almodóvar 2002; Maia et al. 2006; Sánchez-Hernández and Cobo 2012). Thus, fish abundance was studied at three levels: (i) YOY, (ii) sub-adults (immature individuals, excluding YOY) and (iii) adults (sexually mature individuals).

\section{Timing of spawning and hatching}

Trout spawning and fry emergence in the River Tormes usually take place in December and March-April, respectively (Alonso-González 2003). The spawning seasons of nase and chub may overlap, usually extending from May to June (Doadrio et al. 2011 and references therein), but their hatching periods are largely unknown and no specific studies have yet been conducted. Their incubation periods are likely to be shorter than in trout and fry emergence is likely to occur in late spring (May and June) as in other cyprinid species (see Herzig and Winkler 1986; Carrapato and Ribeiro, 2012). Overall, three critical periods in the fish lifecycle were considered in the present study: (i) winter (December-February), coinciding with the trout spawning season, (ii) spring, coinciding with the emergence of trout (early spring, March-April) and spawning and hatching of the cyprinids (late spring, May-June), and (iii) 
summer (July-September). Dividing the spring into early and late seasons was intended to increase the biological relevance of any relationships between species-specific life-history characteristics and the environmental variables.

\section{Statistical analysis}

The non-parametric Kruskal-Wallis test was used to analyze differences in hydrological parameters $\left(\mathrm{Q}_{\mathrm{med}}, \mathrm{Q}_{\max }, \mathrm{Q}_{\min }\right.$ and $\left.\mathrm{Q}_{\text {peak }}\right)$ and water temperature among years. Non-parametric Mann-Kendall $(M K)$ tests and Sen's slope estimator methods were used to test for common temporal trends in the hydro-meteorological variables $\left(\mathrm{Q}_{\operatorname{med}}, \mathrm{Q}_{\max }, \mathrm{Q}_{\min }, \mathrm{Q}_{\text {peak }}\right.$, water temperature, air temperature and precipitation) and fish densities (Worku et al. 2014; Adarsh and Janga Reddy 2015; Ayllón et al. 2015). The $M K$ test checks the null hypothesis of no trend versus the alternative hypothesis of the existence of a decreasing or increasing trend, whereas Sen's slope estimator measures the slope for linear rate of change. Here, the $M K$ test and Sen's slope estimator were computed using the package trend through the functions mk.test and sens.slope, respectively (see Pohlert et al. 2015 for further details).

Canonical correspondence analysis (CCA) was performed using the vegan package for $\mathrm{R}$ program (Oksanen et al. 2015) to examine associations between fish densities (dependent variables) and environmental conditions (independent variables); a suite of 11 environmental variables (water temperature, $\mathrm{Q}_{\text {med }}, \mathrm{Q}_{\max }, \mathrm{Q}_{\mathrm{min}}, \mathrm{Q}_{\text {peak }}$, number of reversals, rate of change and frequency and duration of high and low hydrologic pulses) was used for each season (winter, early spring, late spring and summer, and all seasons combined). The most significant environmental variables for each species were identified using Akaike's information criteria (AIC) (see Oksanen et al. 2015 for further details), and CCA was conducted to test for associations between the environmental variables and the abundance of YOY, sub-adult and 
adult trout, nase and chub. In the resulting ordination diagrams, sampling occasions are represented by dots and environmental variables are represented by arrows, with the length of the arrows indicating the importance of the environmental variables (Ter Braak, 1986). Finally, the strength of association between fish densities and each environmental variable was tested using Pearson's rank correlation. These analyses allowed us to test for associations between fish densities and environmental conditions during fry emergence, the first summer and winter. Additionally, annual recruitment (YOY abundance) was compared with adult abundance using correlation analyses in order to determine the influence of spawning stock size on recruitment success. It was anticipated that, due to the timing of fish sampling (summer) and spawning (winter for trout and late spring for cyprinids), adult abundance in the previous year would have an influence on YOY abundance, but the abundance of adult cyprinids in the same year could also be influential. In all analyses, a significance level of $P=$ 0.05 was used. Statistics and graphical outputs were performed using R 3.2.2 (R Core Team 2012).

\section{Results}

Abiotic parameters

Analyses of 69 years (1943-2012) of hydrological parameters ( $Q_{\text {med }}, Q_{\min }, Q_{\max }$ and $\left.Q_{\text {peak }}\right)$ revealed substantial and significant variations among years (Kruskal-Wallis test; $P<0.05$ in all cases). For instance, the frequency of high $Q_{\text {peak }}$ values (e.g. above $10 \mathrm{~m}^{3} / \mathrm{s}$ ) was higher over the fish data series (46.7\%) than previously $(29.4 \%)$. Long-term trends in hydrometeorological variables showed some significant trends (Table I), $\mathrm{Q}_{\text {med }}$ in early spring and $\mathrm{Q}_{\max }$ in early and late spring have declined; there were no statistically significant trends for $\mathrm{Q}_{\min }$ and $\mathrm{Q}_{\text {peak }}$ (Table I and Figure 2). Air temperature has increased significantly in all 
seasons except winter, whereas an apparent increasing trend in annual precipitation was not statistically significant.

The River Tormes' flow conditions were typical of snow-rainfall regimes, with peak flows in spring (mainly in March and April) and autumn (mainly in November and December). However, substantial inter-annual differences in the hydrological regime occurred (Figure 3). For example, there was a noticeable lack of peak-flow discharges from July 1998 to October 1999 and from June 2008 to January 2009, with the flow regime relatively stable but very low (Figure 3). In contrast, flows were considerably higher in December $2000\left(\mathrm{Q}_{\max }=37.4\right.$ $\left.\mathrm{m}^{3} / \mathrm{s}\right)$, October $2006\left(\mathrm{Q}_{\max }=28.4 \mathrm{~m}^{3} / \mathrm{s}\right)$, April $2008\left(\mathrm{Q}_{\max }=20.3 \mathrm{~m}^{3} / \mathrm{s}\right)$, February $2010\left(\mathrm{Q}_{\max }\right.$ $\left.=19.1 \mathrm{~m}^{3} / \mathrm{s}\right)$ and December $2010\left(\mathrm{Q}_{\max }=16.5 \mathrm{~m}^{3} / \mathrm{s}\right)$. Two seasons with remarkably sudden variations in daily flow conditions were identified, one from October to December and the other coinciding with the cyprinid spawning and larval periods (hatching, fry emergence and early life-stages) in the spring. By contrast, no notable peak-flow discharges occurred in January, February or the summer, with the exception of in 2001, when flow from December to February was very changeable (Figure 4). High-amplitude flows sometimes occurred in a short time period; for example, in April 2008, the mean daily flow $\left(Q_{\text {med }}\right)$ increased almost three-fold in 24 hours (from $7.3 \mathrm{~m}^{3} / \mathrm{s}$ to $20.3 \mathrm{~m}^{3} / \mathrm{s}$ ) and decreased to a similar value 24 hours later (from $20.3 \mathrm{~m}^{3} / \mathrm{s}$ to $9.3 \mathrm{~m}^{3} / \mathrm{s}$ ). Likewise, in December 2000, Q med increased from $4.1 \mathrm{~m}^{3} / \mathrm{s}$ to $37.4 \mathrm{~m}^{3} / \mathrm{s}$ in 24 hours and then took 3 days to fall (from $37.4 \mathrm{~m}^{3} / \mathrm{s}$ to $4.55 \mathrm{~m}^{3} / \mathrm{s}$ ).

Annual mean water temperatures ranged from $9.5^{\circ} \mathrm{C}$ to $12.5^{\circ} \mathrm{C}$, but no statistically significant inter-annual differences were found (Kruskal-Wallis test; $P>0.05$ ) and the apparent increasing trend in the annual mean water temperature time series was not statistically significant (Table I). By contrast, there was a significant increasing trend in late spring water 
temperatures over the study period (Table I). A similar pattern was observed in all years; minima were recorded in January, with maxima recorded in August or September (except in 2006, when the maximum temperature occurred in July).

\section{Biotic parameters}

Substantial temporal variations in fish densities were observed during the study (Figure 5). Moreover, there was a significant reduction in the densities of YOY chub and nase over the study period (Table II). The frequency and duration of high and low hydrological pulses, as well as $\mathrm{Q}_{\min }, \mathrm{Q}_{\text {peak }}$ and $\mathrm{Q}_{\operatorname{med}}$, had the greatest influence on fish abundance, but there were interspecific and ontogenetic differences in their influence (Figure 6); chub seemed most sensitive to changes in summer flows, whereas nase were most influenced by flow in spring, and trout by flow in spring and winter (Table III). Specifically, $\mathrm{Q}_{\min }$ (winter) and $\mathrm{Q}_{\text {peak }}$ (early spring) had a strong negative influence on trout densities, whereas all environmental variables seemed of equal importance to nase (Figure 6). For chub, the most important environmental variables were $\mathrm{Q}_{\max }$ and the duration and frequency of high hydrological pulses during summer (with a positive influence on chub densities), but other variables were also influential (Figure 6 and Table III). Species-specific correlations between fish densities of each developmental period and environmental variables are provided as supplementary material (Appendix I).

The density of YOY trout appeared to be influenced by flow conditions during fry emergence and early larval period, with the highest densities associated with low $Q_{\text {peak }}$ values in early spring $(R=-0.241 ; P=0.044)$ and a high frequency of low hydrological pulses in late spring $(R=0.250 ; P=0.040)$; no significant correlations with summer environmental conditions were found (Appendix I). The density of YOY nase was negatively correlated with the 
number of flow reversals during the spawning and early larval period (late spring) $(R=-$ 0.294; $P=0.045)$. A number of correlations between the density of YOY chub and environmental conditions in late spring and summer was found (Appendix I). For example, density of YOY chub was positively correlated with the duration of low hydrological pulses during the spawning and early larval period $(R=0.321 ; P=0.028)$. There were also positive correlations between the densities of adult chub and flow conditions (the duration of high hydrological pulses, $\mathrm{Q}_{\max }$ and $\mathrm{Q}_{\mathrm{med}}$ ) in summer (Appendix I).

Recruitment success (YOY density) of trout tended to increase with increasing spawning stock size (adult density in the previous year) $(R=0.374 ; P=0.005)$. By contrast, no statistically significant relationships between recruitment success and the density of adults in the previous year were found for the cyprinid species. However, the density of YOY chub was positively correlated with adult density in the same year $(R=0.709 ; P<0.001)$. Densities of YOY nase were highly correlated with sub-adult, but not adult, density in the same year $(R$ $=0.610 ; P<0.001)$.

\section{Discussion}

This study demonstrates that discharge, especially the timing and magnitude of peak-flows, in the River Tormes is highly variable among years. Moreover, the study corroborates previous observations that the hydrology has changed considerably in recent decades, with substantial reductions in mean spring river discharge but increases in peak-flow discharges (CeballosBarbancho and Morán-Tejeda 2006; Ceballos-Barbancho et al. 2008). These changes have been attributed to shifts in precipitation and air temperature due to climate change (CeballosBarbancho et al. 2008; Morán-Tejeda et al. 2010, 2011). In this study, the temporal analysis of air temperature data revealed that a gradual warming of the area has occurred, but the 
increase in water temperature was statistically significant only during late spring. The latter result should therefore be interpreted with caution, as the length of the data series (17 years) may not be sufficient to ascertain whether or not water temperature is increasing as a consequence of increases in air temperature. Although the increase in air temperature over the study period was gradual, significant changes in hydrology could have occurred before the start of the fish data series. Notwithstanding, inter-annual flow variation during the fish time series was high, thereby facilitating assessments of the influence of hydrology on both fish community structure and population dynamics.

Fish abundances were significantly influenced by the frequency and duration of high and low hydrological pulses, but there were interspecific and ontogenetic differences in their influence. For example, chub seemed most sensitive to changes in summer flows, whereas nase were most influenced by flow in spring, and trout by flow in spring and winter. The shifts in environmental conditions in the headwater of the River Tormes basin could therefore have negative consequences for the fish populations. Several studies have demonstrated that changes in fish communities are related to abiotic or biotic shifts in ecosystems, such as droughts or floods, habitat degradation, the introduction of exotic species, and human alterations of river channels or flow regimes (Jackson et al. 2001; Bernardo et al. 2003; Gido et al. 2010). Habitat degradation, flow regulation and exotic species do not affect the fish assemblage in this study, because the headwater of the River Tormes basin is oligotrophic and not polluted, the habitat has not been modified, no significant flow regulation has been implemented (González del Tánago and García de Jalón 1984; Alonso-González et al. 2008), and the fish community is composed entirely of four native species. By contrast, the present study supports the hypothesis that interannual variations in fish populations may be linked to changes in environmental conditions, especially the frequency and duration of high and low 
hydrological pulses in spring. Despite the growing interest in the role of biotic factors, such as intra- and interspecific competition on fish assemblages (e.g. Jackson et al. 2001; Forrester et al.2006), we did not find any relationship between trout and cyprinid abundance. Thus, the present study suggests hydrology as the most important factor influencing fish assemblage structure.

Although difficult to separate the key factors influencing the recruitment success of fishes, flow conditions during the spawning season, egg incubation and/or fry emergence may be important (e.g. Nicola et al. 2009; Piffady et al. 2010; Cowx et al. 2012). The sudden variations in the daily flow of the River Tormes during spring as a consequence of snow melt may therefore have negative consequences for the recruitment success of fishes, especially if high daily peak-flow discharges occur during egg incubation and/or fry emergence. Indeed, YOY trout abundance was negatively correlated with high peak-flows $\left(\mathrm{Q}_{\text {peak }}\right)$ during fry emergence and the early larval period (in early spring; Alonso-González 2003; Nicola et al. 2009). Therefore, congruent with observations elsewhere (e.g. Alonso-González et al. 2008; Nicola et al. 2009), our results suggest that, in addition to the timing of spring floods associated with snow melt, the frequency and magnitude of fluctuations pulses (here measured as daily flow) can also have an influence on recruitment success. Additionally, there was a positive influence of the duration of low hydrological pulses during the spawning and early larval period (in late spring) on the recruitment success of chub, whereas the density of YOY nase was negatively correlated with the number of flow reversals during the early larval period. The YOY cyprinids may be indirectly affected by sudden variations in daily flow conditions during spring as high peak-flow discharges coincided with the spawning and egg incubation seasons of these species, although YOY nase seemed more vulnerable than chub to daily variations. This suggests that cyprinid recruitment should be 
enhanced when flows are relatively stable (no sudden daily variations) and low (here measured as the duration of low hydrological pulses) during spring. However, extreme flow reductions between late spring and early summer could have a negative impact on the recruitment success of the cyprinid species because of their spawning preferences, i.e. lithophilic spawners using shallow nests close to the shore (e.g. Balon 1975; Melcher and Schmutz 2010). For example, eggs could dry out, be exposed to predators or even damaged by anglers walking on spawning habitats, but also YOY cyprinids can be isolated in areas that dry in late summer (J. Sánchez-Hernández personal observation).

Our study highlights the importance of the combination of environmental factors and spawning stock size in understanding temporal variations in fish populations through recruitment success. The relationship between spawning stock size and subsequent recruitment has the potential to play a major part in fish population dynamics (e.g. Elliott 1994; Brodziak et al. 2001). Our results only partially supported the hypothesis that spawning stock size (adult abundance) and subsequent recruitment (YOY abundance in the following year) are highly connected as the relationship was only statistically significant for trout. However, as anticipated due to the timing of fish sampling (summer) and cyprinid spawning (late spring), the abundance of adult cyprinids in the same year can also be influential. Our results thus highlight the possibility that the density of YOY fish can be influenced by the synergistic effects of spawning stock size and flow conditions. Regarding the latter point, an important issue is the capacity of fish to retreat to appropriate refugia when flow conditions are adverse, for example downstream movements in response to low-flow periods in summer (Alexandre et al. 2016) or movement to deep areas (pools) in response to severe droughts (Magoulick and Kobza 2003). Moreover, it seems reasonable to posit that local abundance of potamodromous cyprinid species (here estimated in summer) could be influenced by previous 
fish movements, as their dispersal is highly influenced by flow conditions during spring and early summer (Alexandre et al. 2016). The upstream spawning migration of potamodromous cyprinid species usually begins in mid-late March and ends in June (e.g. Rodriguez-Ruiz and Granado-Lorencio 1992; Encina et al. 2006). Despite nase being considered a good swimmer (Romão et al. 2012), hydrology during the upstream spawning migration might have an influence on the abundance of adult nase, as we found a positive correlation between low hydrological pulses $\left(\mathrm{Q}_{\mathrm{med}}\right)$ in late spring and adult abundance in summer. These findings are in agreement with Alexandre et al. (2016), who found that the dispersal of a potamodromous cyprinid species during late spring and early summer can be positively linked to a decrease in the number of flow falls.

Consideration of the effects of environmental conditions on fish populations should include non-spawning periods in areas where climatic impacts are important. Low dissolved oxygen and high temperatures in Mediterranean running waters during natural summer droughts may have a direct effect on fish populations via mortality (Pires et al. 1999; Bernardo et al. 2003, Magalhães et al. 2007). High water temperatures should be more problematic for trout than the cyprinid species because the upper thermal tolerance is lower in trout than cyprinids (e.g. Elliott 1994; Souchon and Tissot 2012). Elliott (1981) determined $24.7^{\circ} \mathrm{C}$ (up to 7 days) as the upper incipient lethal temperature for trout, but a narrower thermal niche has been described in central Spain (Santiago et al. 2016). The thermal tolerances of nase and chub are unknown (see Elliott 1981; Souchon and Tissot 2012) but, considering the thermal tolerances of closely related species (e.g. Squalius cephalus (L.) and Chondrostoma toxostoma (Vallot, 1837); reviewed by Souchon and Tissot 2012), it may be expected that the upper critical temperatures of chub and nase are higher than that of trout. The upper lethal temperature for adult $S$. cephalus is $30^{\circ} \mathrm{C}$, and the optimal temperature range of adult C. toxostoma varies 
between $16{ }^{\circ} \mathrm{C}$ and $25{ }^{\circ} \mathrm{C}$ (Souchon and Tissot 2012 and references therein). In the present study, mean water temperatures exceeded the upper thresholds for trout in central Spain (between 18.1 and $18.7{ }^{\circ} \mathrm{C}$; Santiago et al. 2016) in July (1999, 2005 and 2006), August (1996, 1999, 2001, 2002, 2004, 2006, 2008, 2009 and 2011) and September (2009 and 2010). Although it is possible that water temperatures in the fish sampling area were lower than at the gauging station (downstream), such conditions are nonetheless likely to be more problematic to trout than cyprinids. For example, thermal habitat losses, leading to decreases in the trout population, could occur if there are significant increases in summer temperatures. Thermal tolerance is generally higher in cyprinids than salmonids (e.g. Elliott 1994; Souchon and Tissot 2012), but species-specific information on the thermal requirements of endemic cyprinids is required to predict the impacts of climate change. Although we have some knowledge of how natural summer droughts affect Mediterranean ichthyofauna (e.g. Magalhães et al. 2007), our study aimed to assist in filling this knowledge gap and enhance the understanding of the impacts of summer environmental conditions on the cyprinid species. Our results are in agreement with Magalhães et al. (2007), who reported that chub abundance declined after droughts. Moreover, this study revealed a positive influence of the duration of high hydrological pulses during the summer on the abundance of adult and YOY chub. However, hydrology may not have the same effect on all developmental periods or in all seasons. For example, whereas unusual high-flow conditions during the summer appeared to be a significant indicator for different developmental periods (YOY and adults) of chub, the recruitment success of the chub appeared to be favoured by low-flow conditions during late spring.

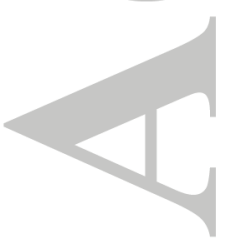


Understanding the influence of environmental conditions on fish populations in the wild is challenging, but essential to improve our knowledge of freshwater ecosystem functioning and predictions of the impacts and implications of future climate scenarios. The present study demonstrated that fish populations can be affected by short-term changes in flow regimes, but such relationships cannot easily be used to extrapolate the likely effects of long-term changes in environmental conditions. Notwithstanding, the study identified important environmental trends in the river system as a consequence of climate change, which may affect fish populations directly or indirectly, and help to understand the fate of these species in the near future. It is widely accepted that global warming should favour cyprinids in comparison with salmonid species (e.g. Daufresne et al. 2003; Matulla et al. 2007; Almodóvar et al. 2012). By contrast, even though projected hydro-climatic changes could lead to increases in local species richness through colonization by warm-water species (Tisseuil et al. 2012 and references therein), future shifts in flow conditions, especially during the spawning and early larval periods, via climate change could have detrimental impacts on riverine cyprinid fish species. More studies are needed, however, because the attention allocated to endemic fish species in the Mediterranean region has been insufficient.

\section{Acknowledgements}

The Servicio Territorial de Medio Ambiente de Ávila (Junta de Castilla y León) enabled this study by granting permission for the fish sampling. The authors would like to thank Rosa San Segundo, Jairo Vicente and Félix López (Junta de Castilla y León). Also, we are especially grateful to Dr. Carlos Alonso González for allowing us to use his data to improve the quality of the dataset used in this study. Flow and water temperature data were gathered by the Duero Basin Water Authority, and meteorological data were provided by the Governmental Agency of Meteorology of Spain - Agencia Estatal de Meteorología. We appreciate constructive 
comments from two anonymous reviewers, which considerably improved the quality of the manuscript. Javier Sánchez-Hernández was supported by a postdoctoral grant from the Galician Plan for Research, Innovation, and Growth 2011-2015 (Plan I2C, Xunta de Galicia).

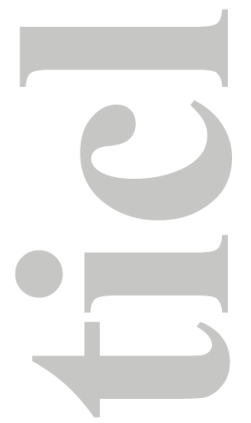

\section{References}

Abrams PA. (2000). The evolution of predator-prey interactions: Theory and evidence. Annual Review of Ecology, Evolution, and Systematics 31: 79-105. doi: 10.1146/annurev.ecolsys.31.1.79

Adarsh S, Janga Reddy M. (2015). Trend analysis of rainfall in four meteorological subdivisions of southern India using nonparametric methods and discrete wavelet transforms. Internacional Journal of Climatology 35: 1107-1124. doi: 10.1002/joc. 4042

Alexandre CM, Almeida PR, Neves T, Mateus CS, Costa JL, Quintella BR. (2016). Effects of flow regulation on the movement patterns and habitat use of a potamodromous cyprinid species. Ecohydrology doi: 10.1002/eco.1638.

Almodóvar A, Nicola GG, Ayllón D, Elvira B. (2012). Global warming threatens the persistence of Mediterranean brown trout. Global Change Biology 18: 1549-1560. doi: $10.1111 / \mathrm{j} .1365-2486.2011 .02608 . \mathrm{x}$

Alonso-González C. (2003). Caracterización de la dinámica de poblaciones de trucha común (Salmo trutta L.) en la cuenca alta del rio Tormes y de los principales factores que influyen en ella. PhD thesis, Polytechnic University of Madrid, Madrid, Spain. (In Spanish) 
Alonso-González C, Gortázar J, Baeza Sanz D, García de Jalón D. (2008). Dam function rules based on brown trout flow requirements: design of environmental flow regimes in regulated streams. Hydrobiologia 609: 253-262. doi: 10.1007/s10750-008-9408-y

Ayllón D, Railsback SF, Vincenzi S, Groeneveld J, Almodóvar A, Grimm V. (2015). InSTREAM-Gen: Modelling eco-evolutionary dynamics of trout populations under anthropogenic environmental change. Ecological Modelling 326: 36-53. doi:10.1016/j.ecolmodel.2015.07.026

Balon EK. (1975). Reproductive guilds of fishes: a proposal and definition. Journal of the Fisheries Research Board of Canada 32: 821-864. doi: 10.1139/f75-110

Beitinger TL, Bennett WA, McCauley RW. (2000). Temperature tolerances of North American freshwater fishes exposed to dynamic changes in temperature. Environmental Biology of Fishes 58: 237-275. doi: 10.1023/A:1007676325825

Bejarano MD, Marchamalo M, García de Jalón D, González del Tánago M. (2010). Flow regime patterns and their controlling factors in the Ebro basin (Spain). Journal of Hydrology 385: 323-335. doi: 10.1016/j.jhydrol.2010.03.001

Bernardo JM, Ilhéu M, Matono P, Costa AM. (2003). Interannual variation of fish assemblage structure in a Mediterranean river: implications of stream flow on the dominance of native or exotic species. River Research and Applications 19: 521-532. doi: $0.1002 /$ rra.726

Brodziak JKT, Overholtz WJ, Rago PJ. (2001). Does spawning stock affect recruitment of New England groundfish? Canadian Journal of Fisheries and Aquatic Sciences 58: 306-318. doi: 10.1139/f00-243

Buisson L, Grenouillet G, Villéger S, Canal J, Laffaille P. (2013). Toward a loss of functional diversity in stream fish assemblages under climate change. Global Change Biology 19: $387-400$. doi: $10.1111 / \mathrm{gcb} .12056$ 
Carrapato C, Ribeiro F. (2012). Larval development of the Iberian cyprinid Anaecypris hispanica. Limnetica 31: 119-128.

Cattanéo F, Carrel G, Lamouroux N, Breil P. (2001). Relationship between hydrology and cyprinid reproductive success in the Lower Rhône at Montélimar, France. Archiv für Hydrobiologie 151: 427-450.

Cattanéo F, Lamouroux N, Breil P, Capra H. (2002). The influence of hydrological and biotic processes on brown trout (Salmo trutta) population dynamics. Canadian Journal of Fisheries and Aquatic Sciences 59: 12-22. doi: 10.1139/f01-186

Ceballos-Barbancho A, Morán-Tejeda E. (2006). Evolución de las aportaciones hídricas en una cuenca de montaña del Sistema Central: cabecera fluvial del río Tormes (19412004). Cuadernos de Investigación Geográfica 32: 7-28. (In Spanish)

Ceballos-Barbancho A, Morán-Tejeda E, Luengo-Ugidos MA, Llorente-Pinto JM. (2008). Water resources and environmental change in a Mediterranean environment: The south-west sector of the Duero river basin (Spain). Journal of Hydrology 351: 126138. doi: 10.1016/j.jhydrol.2007.12.004

Closs GP, Lake PS. (1996). Drought, differential mortality and the coexistence of a native and an introduced fish species in a south east Australian intermittent stream. Environmental Biology of Fishes 47: 17-26. doi: 10.1007/BF00002376

Cowx IG, Noble RA, Nunn AD, Bolland JD, Walton S, Peirson G, Harvey JP. (2012). Flow requirements of non-salmonids. Fisheries Management and Ecology 19: 548-556. doi: $10.1111 /$ fme.12017

Daufresne M, Roger MC, Capra H, Lamouroux N. (2003). Long-term changes within the invertebrate and fish communities of the Upper Rhône River: effects of climatic factors. Global Change Biology 10: 124-140. doi: 10.1046/j.1529-8817.2003.00720.x 
Doadrio I, Perea S, Garzón-Heydt P, González JL. (2011). Ictiofauna Continental Española. Bases para su seguimiento. DG Medio Natural y Política Forestal - MARM, Madrid, Spain. (In Spanish)

Elliott JM. (1981). Some aspects of thermal stress on freshwater teleosts. In: Stress and fish, Pickering AD (ed). Academic Press: London; 209-245.

Elliott JM. (1994). Quantitative ecology and the brown trout. Oxford University Press, Oxford, UK.

Elliott JM, Elliott JA. (2010). Temperature requirements of Atlantic salmon Salmo salar, brown trout Salmo trutta and Arctic charr Salvelinus alpinus: predicting the effects of climate change. Journal of Fish Biology 77: 179-1817. doi: 10.1111/j.10958649.2010.02762.x

Encina L, Rodríguez-Ruiz A, Granado-Lorencio C. (2006). The Iberian ichthyofauna: ecological contributions. Limnetica 25: 331-350.

Forrester GE, Evans B, Steele MA, Vance RR. (2006). Assessing the magnitude of intra and and interspecific competition in two coral reef fishes. Oecologia 148: 632-40. doi: $10.1007 / \mathrm{s} 00442-006-0397-0$

Freyhof J, Brooks E. (2011). European Red List of Freshwater Fishes. Publications Office of the European Union, Luxembourg.

Gido KB, Dodds WK, Eberle ME. (2010). Retrospective analysis of fish community change during a half-century of land-use and stream flow changes. Journal of the North American Benthological Society 29: 970-987. doi: 10.1899/09-116.1

Giorgi F, Lionello P. (2008). Climate change projections for the Mediterranean region. Global and Planetary Change 63: 90-104. doi: 10.1016/j.gloplacha.2007.09.005 
Gómez-Navarro JJ, Montávez JP, Jerez S, Jiménez-Guerrero P, Lorente-Plazas R, GonzálezRouco JF, Zorita E. (2011). A regional climate simulation over the Iberian Peninsula for the last millennium. Climate of the Past 7: 451-472. doi:10.5194/cp-7-451-2011

González del Tánago M, García de Jalón D. (1984). Desarrollo de un índice biológico para estimar la calidad de las aguas en la Cuenca del Duero. Limnetica 1: 263-272. (In Spanish)

Graham CT, Harrod C. (2009). Implications of climate change for the fishes of the British Isles. Journal of Fish Biology 74: 1143-1205. doi: 10.1111/j.1095-8649.2009.02180.x

Herzig A, Winkler H. (1986). The influence of temperature on the embryonic development of three cyprinid fishes, Abramis brama, Chalcalburnus chalcoides mento and Vimba vimba. Journal of Fish Biology 28: 171-181. doi: 10.1111/j.10958649.1986.tb05155.x

Jackson DA, Mandrak NE. (2002). Changing fish biodiversity: predicting the loss of cyprinid biodiversity due to global climate change. In: Fisheries in a Changing Climate, McGinn NA (ed). American Fisheries Society: Maryland (USA), 89-98.

Jackson DA, Peres-Neto PR, Olden JD. (2001). What controls who is where in freshwater fish communities - the roles of biotic, abiotic, and spatial factors. Canadian Journal of Fisheries and Aquatic Sciences 58: 157-170. doi: 10.1139/f00-239

Jonsson B, Jonsson N. (2009). A review of the likely effects of climate change on anadromous Atlantic salmon Salmo salar and brown trout Salmo trutta, with particular reference to water temperature and flow. Journal of Fish Biology 75: 23812447. doi: 10.1111/j.1095-8649.2009.02380.x

Kiernan JD, Moyle PB. (2012). Flows, droughts, and aliens: factors affecting the fish assemblage in a Sierra Nevada, California, stream. Ecological Applications 22: 11461161. doi: 10.1890/11-1047.1 
Knight RR, Murphy JC, Wolfe WJ, Saylor CF, Wales AK. (2014). Ecological limit functions relating fish community response to hydrologic departures of the ecological flow regime in the Tennessee River basin, United States. Ecohydrology 7: 1260-1280. doi: $10.1002 /$ eco. 1460

Lobón-Cerviá J, Elvira B. (1981). Edad, crecimiento y reproducción de la boga de río (Chondrostoma polylepis polylepis Stein., 1865) en el embalse de Pinilla (rio Lozoya). Boletín - Instituto Español de Oceanografía 6: 199-213. (In Spanish)

Lobón-Cerviá J, Montañes C, Sostoa A. (1986). Reproductive ecology and growth of a population of brown trout (Salmo trutta L.) in an aquifer-fed stream of Old Castile (Spain). Hydrobiologia 135: 81-94. doi: 10.1007/BF00006461

Magalhães MF, Beja P, Schlosser IJ Collares-Pereira MJ. (2007). Effects of multi-year droughts on fish assemblages of seasonally drying Mediterranean streams. Freshwater Biology 52: 1494-1510. doi: 10.1111/j.1365-2427.2007.01781.x

Magoulick DD, Kobza RM. (2003). The role of refugia for fishes during drought: a review and synthesis. Freshwater Biology 48: 1186-1198. doi: 10.1046/j.13652427.2003.01089.x

Maia HMS, Maia CFQ, Pires DFC, Valente ACN. (2006). Biology of the iberian chub (Squalius carolitertii) in an atlantic-type stream (river Lima basin-north Portugal). A preliminary approach. Limnetica 25 : 713-722.

Matthews WJ, Maness JD. (1979). Critical thermal maxima, oxygen tolerances and success of cyprinid fishes in a Southwestern river. American Midland Naturalist 102: 374 377.

Matthews WJ, Marsh-Matthews E. (2003). Effects of drought on fish across axes of space, time and ecological complexity. Freshwater Biology 48: 1232-1253. doi: 10.1046/j.1365-2427.2003.01087.x 
Matulla C, Schmutz S, Melcher A, Gerersdorfer T, Haas P. (2007). Assessing the impact of a downscaled climate change simulation on the fish fauna in an Inner-Alpine River. International Journal of Biometeorology 52: 127-137. doi 10.1007/s00484-007-01076

Melcher A, Schmutz S. (2010). The importance of structural features for spawning habitat of nase Chondrostoma nasus (L.) and barbel Barbus barbus (L.) in a pre-alpine river. River Systems 19: 33-42. doi: 10.1127/1868-5749/2010/019-0033

Morán-Tejeda E, Ceballos-Barbancho A, Llorente-Pinto JM. (2010). Hydrological response of Mediterranean headwaters to climate oscillations and land-cover changes: The mountains of Duero River basin (Central Spain). Global and Planetary Change 72: 3949. doi: 10.1016/j.gloplacha.2010.03.003

Morán-Tejeda E, López-Moreno JI, Ceballos-Barbancho A, Vicente-Serrano SM. (2011). River regimes and recent hydrological changes in the Duero basin (Spain). Journal of Hydrology 404: 241-258. doi: 10.1016/j.jhydrol.2011.04.034

Nicola GG, Almodóvar A. (2002). Reproductive traits of stream-dwelling brown trout Salmo trutta in contrasting neighbouring rivers of central Spain. Freshwater Biology 47: 1353-1365. doi: 10.1046/j.1365-2427.2002.00866.x

Nicola GG, Almodóvar A, Elvira B. (2009). Influence on hydrologic attributes on brown trout recruitment in low-latitude range margins. Oecologia 160: 515-524. doi: $10.1007 / \mathrm{s} 00442-009-1317-\mathrm{x}$

Nunn AD, Frear PA, Lee M, Cowx IG. (2010). Is there evidence for a shift in fish growth and recruitment success linked to climate change? Journal of Fish Biology 77: 1780-1792. doi: $10.1111 / \mathrm{j} .1095-8649.2010 .02751 . \mathrm{x}$

Nunn AD, Harvey JP, Britton JR, Frear PA, Cowx IG. (2007). Fish, climate and the Gulf Stream: the influence of abiotic factors on the recruitment success of cyprinid fishes 
in lowland rivers. Freshwater Biology 52: 1576-1586. doi: 10.1111/j.13652427.2007.01789.x

Oksanen J, Blanchet FG, Kindt R, Legendre P, Minchin PR, O’Hara RB, Simpson GL, Solymos P, Stevens MHH, Wagner H. (2015). Vegan: Community Ecology Package. $\mathrm{R}$ package version 2.3-0. https://cran.r-project.org/web/packages/vegan/index.html [accessed 4 March 2016].

Petersen CGJ. (1982). Fiskens biologiske forhold I Holboek Fjord, 1890-91. Beretning fra den Danske Biologiske Statio 1: 121-183.

Piffady J, Souchon Y, Capra H, Parent E. (2010). Quantifying the effects of temperature and flow regime on the abundance of $0+$ cyprinids in the upper River Rhone using Bayesian hierarchical modelling. Freshwater Biology 55: 2359-2374. doi: $10.1111 / \mathrm{j} .1365-2427.2010 .02453 . x$

Pires AM, Cowx IG, Coelho MM. (1999). Seasonal changes in fish community structure of intermittent streams in the middle reaches of the Guadiana basin, Portugal. Journal of Fish Biology 54: 235-249. doi: 10.1111/j.1095-8649.1999.tb00827.x

Pohlert T. (2015). trend: Non-Parametric Trend Tests and Change-Point Detection. R package version 0.0 .1 https://cran.r-project.org/web/packages/trend/index.html [accessed 4 March 2016].

R Core Team (2012). R: A Language and Environment for Statistical Computing, R Foundation for Statistical Computing: Vienna, Austria.

Richter BD, Baumgartner JV, Powell J, Braun DP. (1996). A Method for Assessing Hydrologic Alteration within Ecosystems. Conservation Biology 10: 1163-1174. doi: 10.1046/j.1523-1739.1996.10041163.x 
Rodriguez-Ruiz A, Granado-Lorencio C. (1992). Spawning period and migration of three species of cyprinids in a stream with Mediterranean regimen (SW Spain). Journal of Fish Biology 41: 545-556. doi: 10.1111/j.1095-8649.1992.tb02682.x

Romão F, Quintella BR, Pereira TJ, Almeida PR. (2012). Swimming performance of two Iberian cyprinids: the Tagus nase Pseudochondrostoma polylepis (Steindachner, 1864) and the bordallo Squalius carolitertii (Doadrio, 1988). Journal of Applied Ichthyology 28: 26-30. doi: 10.1111/j.1439-0426.2011.01882.x

Sánchez-Hernández J, Cobo F. (2012). Summer differences in behavioural feeding habits and use of feeding habitat among brown trout (Pisces) age classes in a temperate area. Italian Journal of Zoology 79: 468-478. doi: 10.1080/11250003.2012.670274

Sánchez-Hernández J, Cobo F, Amundsen P-A. (2015). A simple approach for assigning the conservation status of freshwater fish based on their natural variability - a case study from the Iberian Ecoregion. Fisheries Management and Ecology 22: 125-133. doi: 10.1111/fme. 12103

Santiago JM, García de Jalón D, Alonso C, Solana J, Ribalaygua J, Pórtoles J, Monjo R. (2016). Brown trout thermal niche and climate change: expected changes in the distribution of cold-water fish in central Spain. Ecohydrology. doi: 10.1002/eco.1653.

Souchon Y, Tissot L. (2012). Synthesis of thermal tolerances of the common freshwater fish species in large Western Europe rivers. Knowledge and management of aquatic ecosystems 405: 48. doi: 10.1051/kmae/2012008

Taniguchi Y, Rahel FJ, Novinger DC, Gerow KG. (1998). Temperature mediation of competitive interactions among three fish species that replace each other along longitudinal stream gradients. Canadian Journal of Fisheries and Aquatic Sciences 55: 1894-1901. doi: 10.1139/f98-072 
Tedesco PA, Oberdorff T, Cornu J-F, Beauchard O, Brosse S, Dürr HH, Grenouillet G, Leprieur F, Tisseuil C, Zaiss R, Hugueny B. (2013). A scenario for impacts of water availability loss due to climate change on riverine fish extinction rates. Journal of Applied Ecology 50: 1105-1115. doi: 10.1111/1365-2664.12125

Ter Braak CJF. (1986). Canonical correspondence analysis: a new eigenvector technique for multivariate direct gradient analysis. Ecology 67: 1167-1179. doi: 10.2307/1938672

Tisseuil C, Vrac M, Grenouillet G, Wade A, Gevrey M, Oberdorff T, Grodwohl JB, Lek S. (2012). Strengthening the link between climate, hydrological and species distribution modelling to assess the impacts of climate change on freshwater biodiversity. Science of the Total Environment 424: 193-201. doi: 10.1016/j.scitotenv.2012.02.035

Vautard R, Gobiet A, Sobolowski S, Kjellström E, Stegehuis A, Watkiss P, Mendlik T, Landgren O, Nikulin G, Teichmann C, Jacob D. (2014). The European climate under a $2^{\circ} \mathrm{C}$ global warming. Environmental Research Letters 9: 034006. doi: 10.1088/1748$9326 / 9 / 3 / 034006$

Vincenzi S, Satterthwaite WH, Mangel M. (2012). Spatial and temporal scale of densitydependent body growth and its implications for recruitment, population dynamics and management of stream-dwelling salmonid populations. Reviews in Fish Biology and Fisheries 22: 813-825. doi: 10.1007/s11160-011-9247-1

Worku FF, Werner M, Wright N, van der Zaag P, Demissie SS. (2014). Flow regime change in an endorheic basin in southern Ethiopia. Hydrology and Earth System Sciences 18: 3837-3853. doi: 10.5194/hess-18-3837-2014.

Zanchettin D, Traverso P, Tomasino M. (2008). Po River discharges: A preliminary analysis of a 200-year time series. Climatic Change 89: 411-433. doi: 10.1007/s10584-0089395-Z 
Zippin C. (1956). An evaluation of the removal method of estimating animal populations.

Biometrics 12: 163-189.
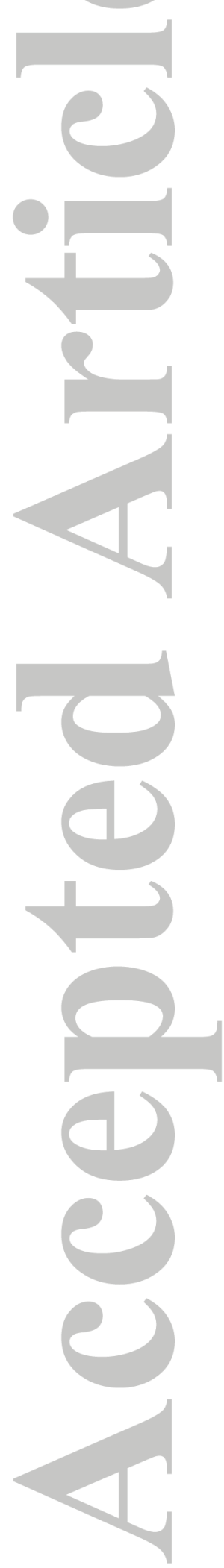
Table I. Trend analyses of hydro-meteorological variables in the River Tormes basin (Spain) over the study period. Significant results are marked in bold.

\begin{tabular}{|c|c|c|c|}
\hline & \multicolumn{2}{|c|}{ Mann-Kendall $(M K)$ test } & \multirow{2}{*}{ Sen's slope } \\
\hline & $z$ & $P$ & \\
\hline \multicolumn{4}{|c|}{ Annual } \\
\hline $\mathrm{Q}_{\mathrm{mec}}$ & -2.10 & $\mathbf{0 . 0 3 3}$ & -0.011 \\
\hline $\mathrm{Q}_{\max }$ & -3.00 & 0.003 & -0.059 \\
\hline $\mathrm{Q}_{\min }$ & 0.60 & 0.517 & 0.002 \\
\hline$Q_{\text {peak }}$ & 1.50 & 0.126 & 0.124 \\
\hline Air temperature & 4.00 & $<0.001$ & 0.070 \\
\hline Precipitation & 0.30 & 0.802 & 0.533 \\
\hline Water temperature & 1.60 & 0.117 & 0.082 \\
\hline \multicolumn{4}{|c|}{ Winter } \\
\hline $\mathrm{Q}_{\text {med }}$ & -0.70 & 0.508 & -0.005 \\
\hline $\mathrm{Q}_{\max }$ & -1.40 & 0.154 & -0.035 \\
\hline $\mathrm{Q}_{\min }$ & 1.80 & 0.071 & 0.006 \\
\hline$Q_{\text {peak }}$ & -0.60 & 0.569 & -0.029 \\
\hline Air temperature & 1.60 & 0.103 & 0.033 \\
\hline Precipitation & -0.30 & 0.752 & -0.207 \\
\hline Water temperature & -0.50 & 0.621 & -0.043 \\
\hline \multicolumn{4}{|c|}{ Early Spring } \\
\hline $\mathrm{Q}_{\text {med }}$ & -2.50 & 0.011 & -0.029 \\
\hline $\mathrm{Q}_{\max }$ & -2.90 & 0.003 & -0.089 \\
\hline $\mathrm{Q}_{\min }$ & -0.70 & 0.475 & -0.004 \\
\hline $\mathrm{Q}_{\text {peak }}$ & -0.10 & 0.911 & -0.006 \\
\hline Air temperature & 3.90 & $<0.001$ & 0.100 \\
\hline Precipitation & 0.80 & 0.441 & 0.612 \\
\hline Water temperature & 0.10 & 0.934 & 0.014 \\
\hline \multicolumn{4}{|c|}{ ate Spring } \\
\hline $\mathrm{Q}_{\text {med }}$ & -1.60 & 0.111 & -0.010 \\
\hline $\mathrm{Q}_{\max }$ & -3.10 & 0.002 & -0.042 \\
\hline $\mathrm{Q}_{\min }$ & 0.20 & 0.807 & 0.001 \\
\hline $\mathrm{Q}_{\text {peak }}$ & -1.50 & 0.131 & -0.053 \\
\hline Air temperature & 3.50 & 0.001 & 0.125 \\
\hline Precipitation & -0.50 & 0.621 & -0.622 \\
\hline Water temperature & 2.40 & 0.019 & 0.203 \\
\hline \multicolumn{4}{|c|}{ Summer } \\
\hline $\mathrm{Q}_{\mathrm{med}}$ & 0.70 & 0.506 & 0.001 \\
\hline $\mathrm{Q}_{\max }$ & -0.80 & 0.432 & -0.002 \\
\hline $\mathrm{Q}_{\min }$ & 1.90 & 0.063 & 0.001 \\
\hline $\mathrm{Q}_{\text {peak }}$ & -0.80 & 0.398 & -0.007 \\
\hline Air temperature & 2.70 & 0.007 & 0.059 \\
\hline Precipitation & -0.90 & 0.343 & -0.882 \\
\hline Water temperature & 1.50 & 0.127 & 0.124 \\
\hline
\end{tabular}


Table II. Trend analyses of fish density in the River Tormes basin (Spain) over the study period. Data are displayed for each species and developmental period. Significant results are marked in bold.

\begin{tabular}{|c|c|c|c|c|}
\hline & & \multicolumn{2}{|c|}{ Mann-Kendall $(M K)$ test } & \multirow{2}{*}{ Sen's slope } \\
\hline & & $z$ & $P$ & \\
\hline & Trout & & & \\
\hline YOY & & 0.50 & 0.582 & 0.010 \\
\hline Sub-adults & & 1.80 & 0.072 & 0.006 \\
\hline Adults & & 1.60 & 0.099 & 0.003 \\
\hline & Nase & & & \\
\hline YOY & & -2.30 & 0.023 & -0.003 \\
\hline Sub-adults & & -1.30 & 0.193 & -0.031 \\
\hline Adults & & -1.40 & 0.157 & -0.001 \\
\hline & Chub & & & \\
\hline YOY & & -2.20 & 0.027 & -0.003 \\
\hline Sub-adults & & -1.90 & 0.064 & -0.015 \\
\hline Adults & & -1.60 & 0.115 & -0.004 \\
\hline
\end{tabular}


Table III. Environmental variables used in canonical correspondence analysis (CCA) after variable selection based on the forward selection method. Akaike's information criterion (AIC).

\begin{tabular}{|c|c|c|c|c|c|}
\hline Fish species & Description of the variables & Code & AIC & $F$ & $P$ \\
\hline \multicolumn{6}{|l|}{ Trout } \\
\hline & Mean minimum daily flow (total) & V1 & -102.093 & 4.996 & 0.020 \\
\hline & Mean minimum daily flow (winter) & $\mathrm{V} 2$ & -101.769 & 4.659 & 0.025 \\
\hline & Duration of high hydrological pulses (total) & V3 & -101.680 & 4.566 & 0.030 \\
\hline & Frequency of low hydrological pulses (late spring) & V4 & -101.306 & 4.180 & 0.030 \\
\hline & Maximum peak-flow (early spring) & V5 & -100.929 & 3.792 & 0.035 \\
\hline & Maximum peak-flow (total) & V6 & -100.847 & 3.708 & 0.035 \\
\hline & Mean daily flow (total) & V7 & -100.803 & 3.664 & 0.040 \\
\hline & Duration of low hydrological pulses (late spring) & V8 & -100.637 & 3.494 & 0.050 \\
\hline & Frequency of low hydrological pulses (early spring) & V9 & -24.316 & 6.970 & 0.020 \\
\hline & Duration of low hydrological pulses (early spring) & V10 & -24.316 & 6.9703 & 0.020 \\
\hline & Frequency of low hydrological pulses (winter) & V11 & -21.065 & 3.564 & 0.045 \\
\hline & Mean daily flow (late spring) & V12 & -20.089 & 2.586 & 0.050 \\
\hline \multicolumn{6}{|l|}{ Chub } \\
\hline & Mean maximum daily flow (summer) & V13 & -134.05 & 10.582 & 0.005 \\
\hline & Duration of high hydrological pulses (summer) & V14 & -133.69 & 10.152 & 0.010 \\
\hline & Frequency of high hydrological pulses (summer) & V15 & -133.15 & 10.105 & 0.010 \\
\hline & Mean maximum daily flow (total) & V16 & -131.01 & 7.094 & 0.015 \\
\hline & Mean daily flow (summer) & V17 & -130.84 & 6.913 & 0.015 \\
\hline & Maximum peak-flow (total) & V6 & -130.25 & 6.907 & 0.020 \\
\hline & Maximum peak-flow (summer) & V18 & -130.10 & 6.903 & 0.020 \\
\hline & Duration of high hydrological pulses (late spring) & V19 & -129.30 & 5.232 & 0.020 \\
\hline & Mean daily flow (total) & V7 & -129.75 & 5.719 & 0.025 \\
\hline & Duration of low hydrological pulses (total) & V20 & -127.85 & 3.705 & 0.045 \\
\hline
\end{tabular}



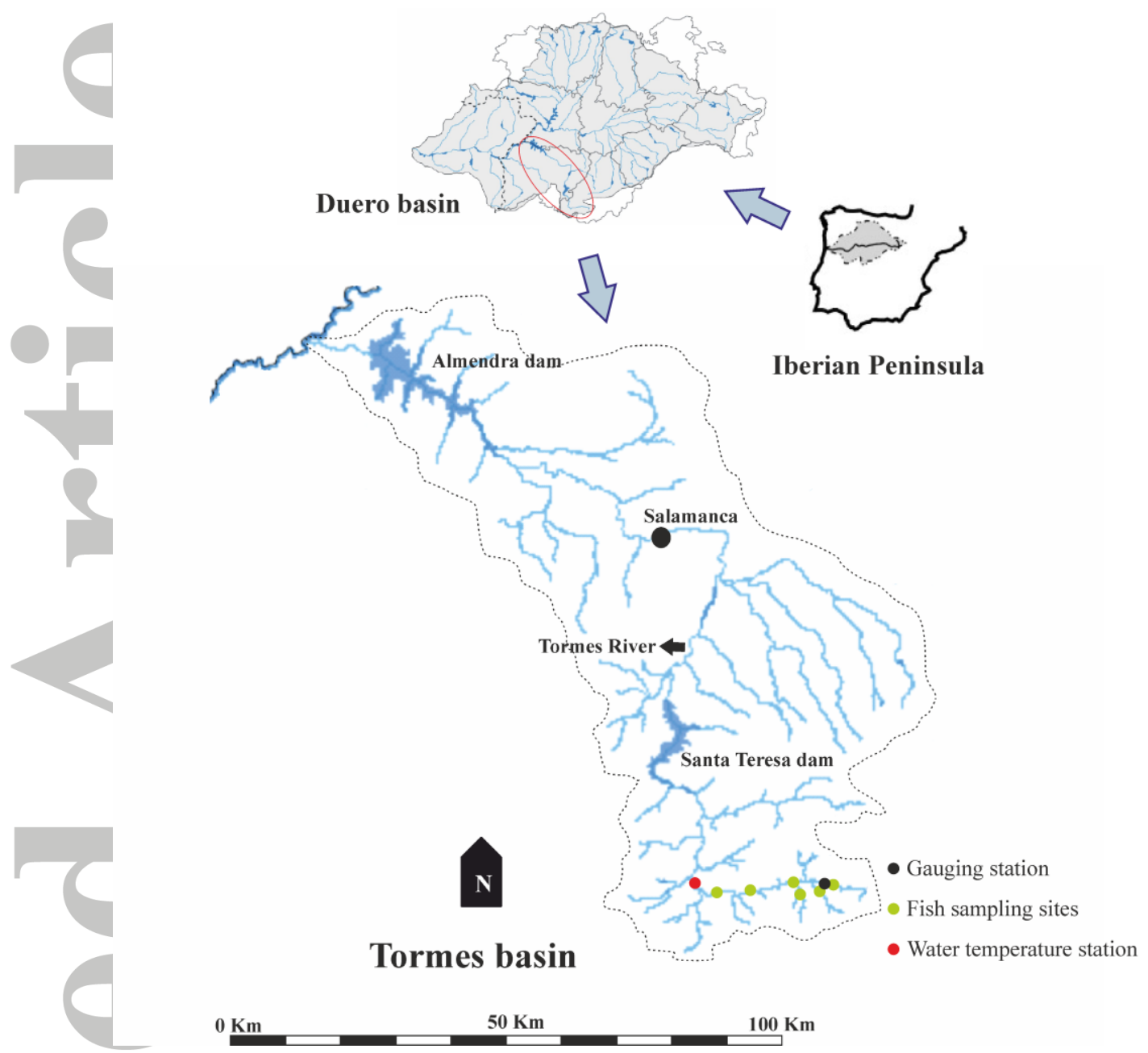

Figure 1. Map of the Iberian Peninsula and Duero basin showing the fish sampling sites, water temperature station and gauging station in the River Tormes basin, Spain. 

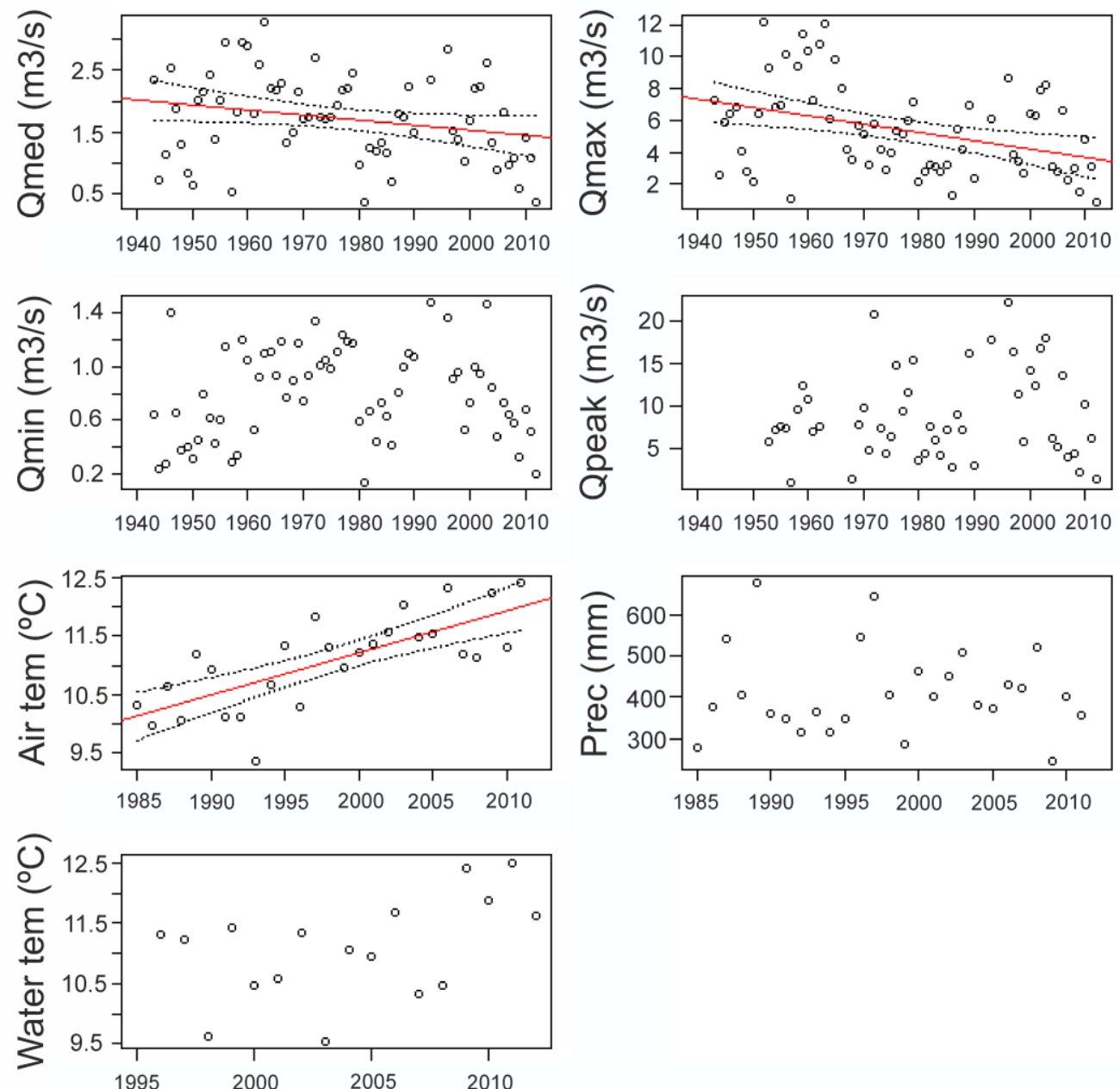

Figure 2. Long-term changes in hydrology, climate (air temperature and precipitation) and water temperature in the River Tormes basin (Spain). Linear trends with 95\% confidence limits are shown only for statistically significant relationships based on Mann-Kendall test (Table I). The hydrological dataset had a gap from 1990-1995 (with the exception of the 1992-1993 hydrological year), and no $Q_{\text {peak }}$ data were available from 1943-1953 and 19631968. 


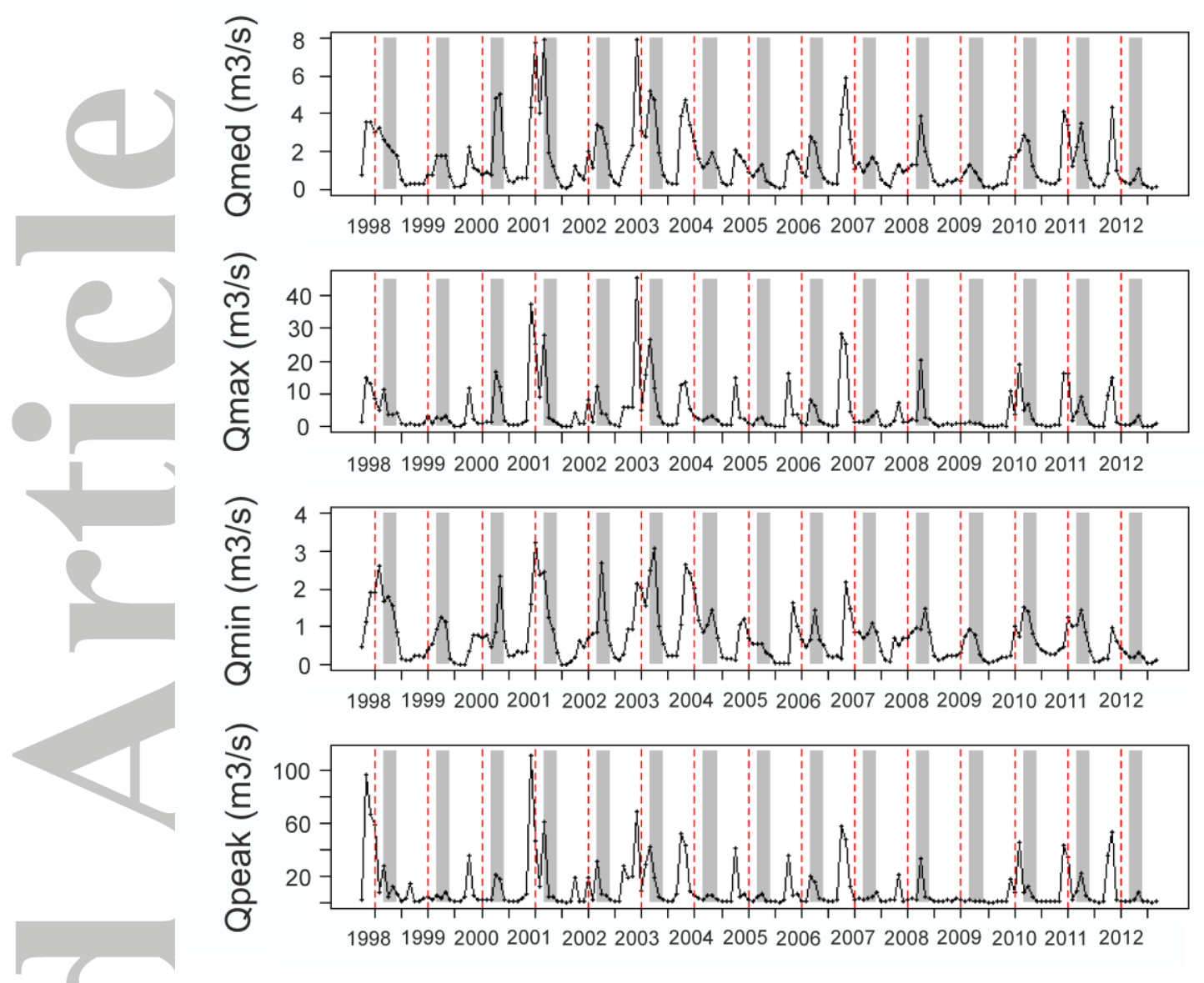

Figure 3. Mean monthly flow $\left(\mathrm{m}^{3} / \mathrm{s}\right)$ in the River Tormes (Spain). Red broken lines show the year turn (1 January) and grey rectangles show the potential fry emergence season (MarchJune) during the fish sampling period (1 October 1997 to 30 September 2012). 

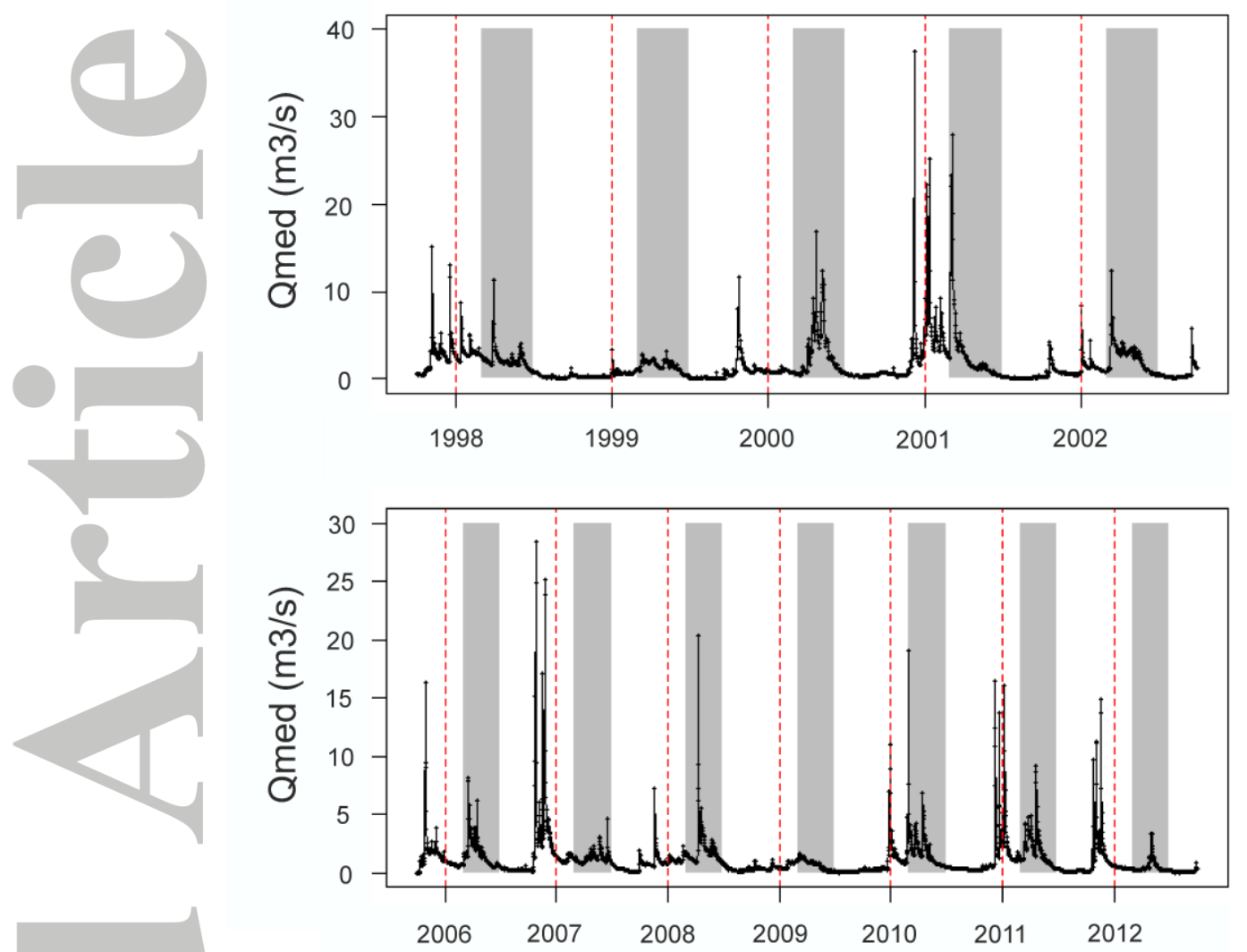

Figure 4. Mean daily flow $\left(\mathrm{m}^{3} / \mathrm{s}\right)$ in the River Tormes (Spain) during the fish sampling period (1 October 1997to 30 September 2012). Red broken lines show the year turn (1 January) and grey rectangles show the potential fry emergence season (March-June). 


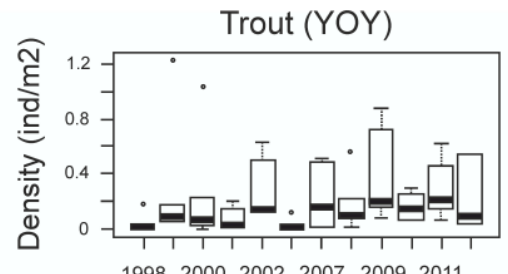

199820002002200720092011

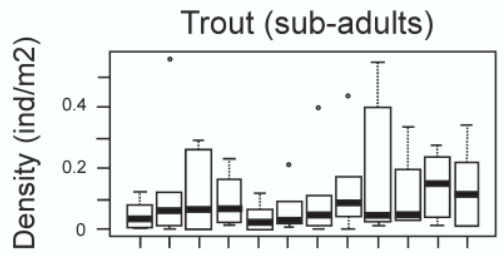

199820002002200720092011

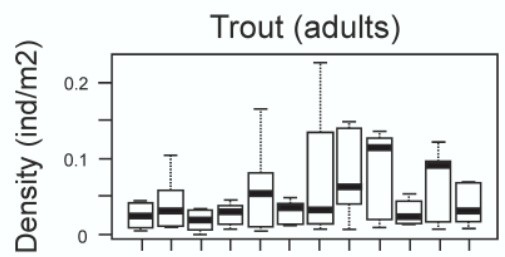

199820002002200720092011

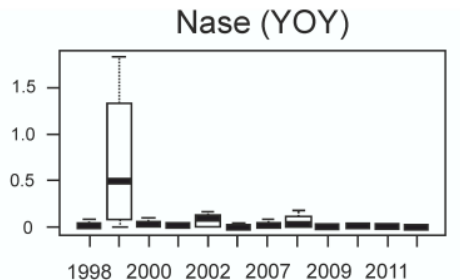

Nase (sub-adults)

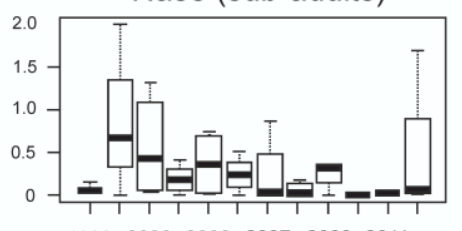

199820002002200720092011

Nase (adults)

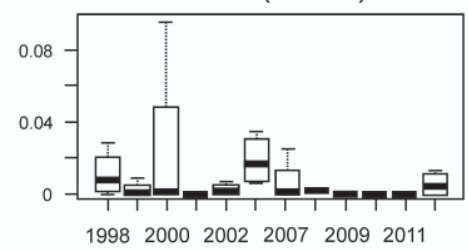

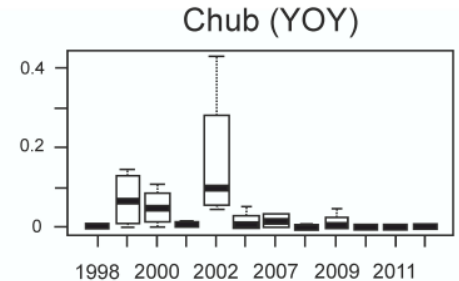

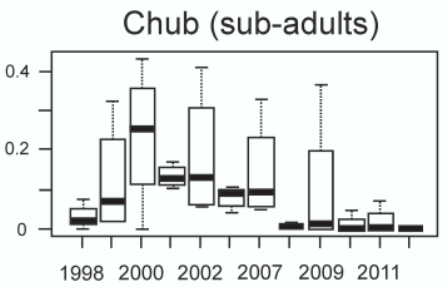

Chub (adults)

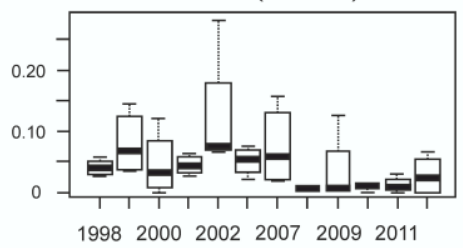

Figure 5. Density $\left(\mathrm{fish} / \mathrm{m}^{2}\right.$ ) of the fish assemblage in the River Tormes (Spain) over time (1998-2012). The boxes show $25^{\text {th }}$ to $75^{\text {th }}$ percentiles and the median (the inner horizontal line in each box). Whiskers above and below the box indicate the $90^{\text {th }}$ and $10^{\text {th }}$ percentiles. 

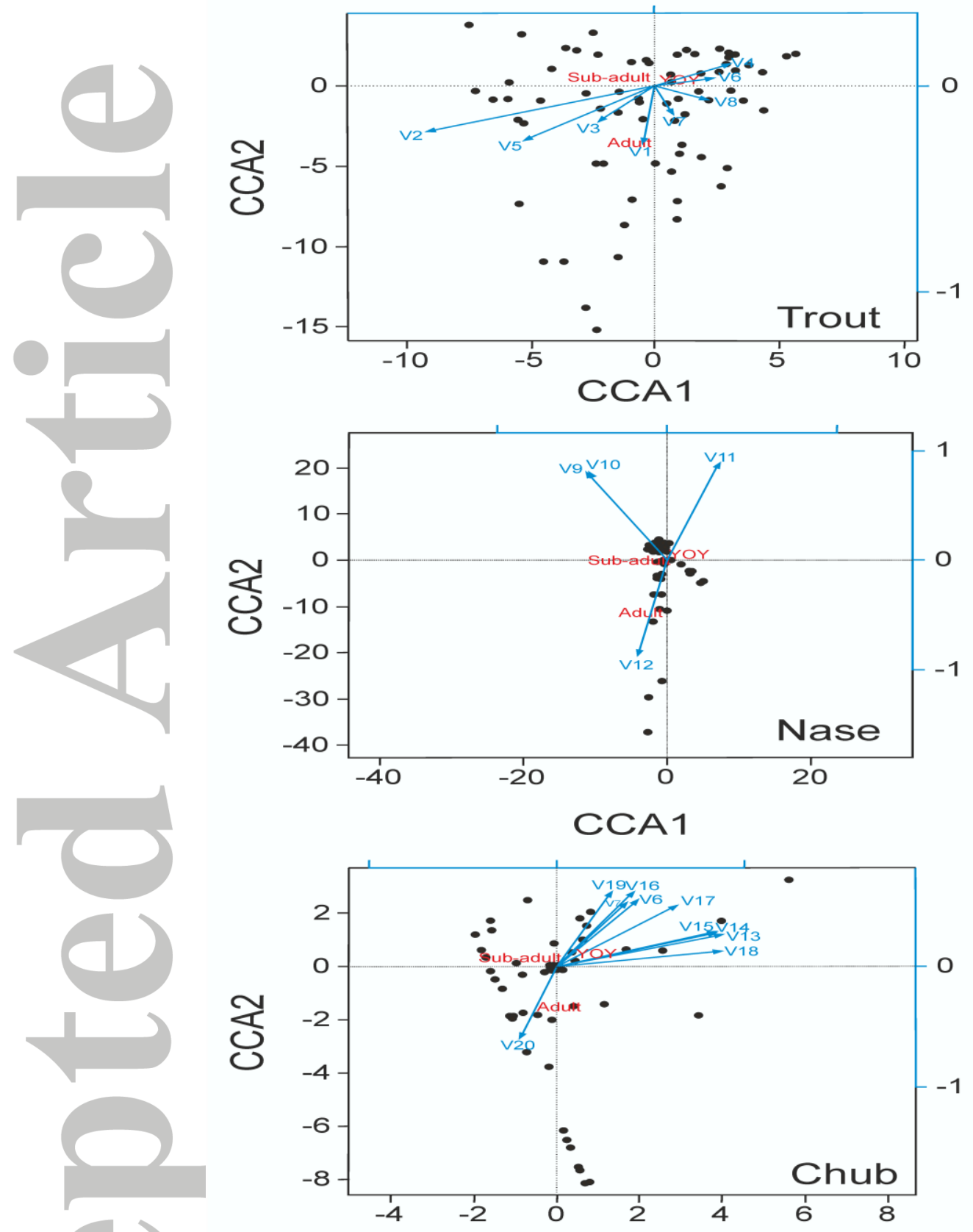

CCA 1

Figure 6. Canonical correspondence analysis (CCA) plot after stepwise forward selection based on fish abundances and selected environmental variables from 1998-2012. Descriptions of the abbreviations are given in Table III. The first two axes of the CCA accounted for 99.9, 100 and $100 \%$ of the total variance for trout, nase and chub, respectively. The length of the arrow is a measure of the importance of the environmental variable and the arrow heads point in the direction of increasing influence. 


\section{Supporting Information}

Appendix I. Pearson's rank correlations between fish abundance and environmental variables.

Only significant results are shown. D25 $=$ duration of low hydrological pulses, D75 = duration of high hydrological pulses, F25 = frequency of low hydrological pulses, F75 = frequency of high hydrological pulses and Temp = water temperature. Definitions of rate, reversals, $\mathrm{Q}_{\text {med }}, \mathrm{Q}_{\max }, \mathrm{Q}_{\min }, \mathrm{Q}_{\text {peak }}$ and $\mathrm{Q}_{\text {flow }}$ are given in "Materials and methods". 